\title{
7 The Alchemical Life of Ernesta Thot - A Romantic Heroine of Art
}

\author{
Marta Kudelska
}

What do we mean when we describe a curator's ways of acting or trying to determine who he actually is? Curating itself is mostly associated with organizing exhibitions - not only dedicated to contemporary art, but also to early art. However, it is the field of contemporary art that we should look at for the starting point of curating history. Curating is a modern practice that dates back to the late decades of the twentieth century. It combines various, often quite different, skills, ranging from specialist knowledge on culture and art through competences related to art management and art criticism to the ability to work with artists to create an exhibition (Brenson, 1998).

Curating contemporary art is a profession strongly dominated by the conviction that the work is rather special, which has often led to the fact that curators are considered to be extremely strong, independent entities operating in the field of contemporary art. Similar to many other "unusual" characters, representatives of this profession are strongly convinced of the individualization of their narratives, but also about the impossibility of creating obvious rules creating the success of a given art curator. This certain enigmatic nature is also associated with what Lucy Lippard mentions in an interview with Hans Ulrich Obrist: a certain amnesia regarding the beginning of curating (Obrist, 2016). Lippard herself admitted that, in her own archive, she did not even have photos from her first exhibitions and artistic shows. Therefore, when we examine the history of curating, we are often doomed to rely on memories, enigmatic notes, or stories about exhibitions that were once carried out.

This openness to interpretations became the starting point for Arthur Danto to create the concept of "artworld," under which a certain community of people, who voluntarily participate in its construction, are hidden, working behind the scene. They have some common sensitivity, aesthetic preferences, but also if they want to exist in this world, they must become its active members. It is this particular group that has the power to define and name what art is and what it is not. 
Danto even goes so far as "elevating" this world and comparing it to the divine world:

The artworld stands to the real world in something like the relationship in which the City of God stands to the Earthly City. Certain objects, like certain individuals, enjoy a double citizenship...

(Danto, 1964, p. 582)

Can we therefore compare the art world to a secret, closed group of people who have gained the knowledge of transforming ordinary objects into art? Following this line of thought, could you compare art curators to alchemists? And what about the characters from this world who, due to the lack of material traces of their activity, were lost in the depths of history? The following text is an attempt to answer these questions by restoring the memory of a forgotten curator - Ernesta Thot. An extraordinary figure who, in her curatorial practice, sought to equalize two worlds - the world of alchemy and the world of art. Thot believed that modern art was governed by rules similar to the alchemical and magical world. This perspective seems extremely interesting for us today, as we are increasingly leaning on exploring the past and searching for answers to describe our present. The story of Ernesta Thot can therefore shed a new light on the development of the profession of a curator of modern art.

For over a century, the figure of Ernesta Thot - a Styrian-Polish art curator - has been one of the many greats of contemporary art lost in the depths of history. Aside from fringe characters and personalities like charlatans, or misfits, schizophrenics, and mystics, no one considered, referred to, or explored her ideas, or similar ideas. In this way, she came to be forgotten, lost and adrift in time, on the tides of history for so long.

\section{Miss Ernesta's Bitterness}

Miss Ernesta (a Miss, as she is said to have never been married), contrary to the contemporary mores of the time, delighted in oneiric, mystical, phantasmatic, surreal, and avant-garde forms of art (Figure 7.1). She advocated cabarets, alchemy, and occultism. Long before the arrival of the postmodernists, she was of the opinion that modernist beliefs about the neutrality of the "White Cube" (art gallery space) were just another myth, and nothing more than a camouflaged element of ideology. In other words, a white, ideal, modernist art space - originating from the Vienna Secession (exhibition pavilion in Vienna) - seemed highly suspicious to her, because she felt that it could be used for ideological warfare, exclusion, and advocating symbolic, political, and economic violence.

Unfortunately, Ernesta never fully developed her idea that the space of the institution of art did not mean anything objective, because it was 


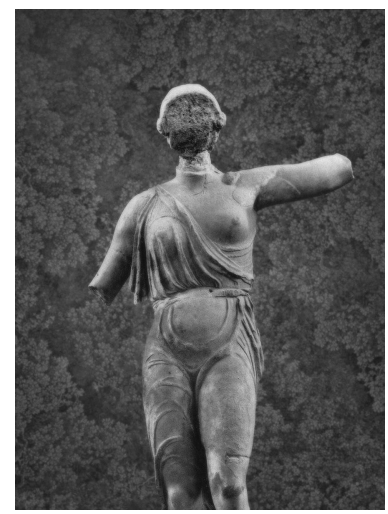

Figure 7.1 Miss Ernesta’s bitterness. Jakub Woynarowski (2012) "Iconoclastia," "Novus Ordo Seclorum" cycle.

only a mirror in which the problems of modern times were reflected. However, it also depicted the growing problem of the instrumentalization of the artistic object. ${ }^{1}$ A growing bitterness towards this instrumentalization led her to turn to a completely different approach in her curatorial research, compared with that of her contemporaries.

\section{Death Did Not Come Quickly}

Ernesta Thot died on 12 August 1936, having fallen into a coma on 20 May earlier that year. As has been the case for other exceptional characters, it all started following an unfortunate - completely unexpected incident: Ernesta had collapsed while strolling through the garden, having choked on the smell of a strange golden flower. ${ }^{2}$ What makes this story more extraordinary is that these dates coincided with the alleged illness and death of Michał Sędziwój, the "Prince of Polish Alchemy."

Like many other visionaries, Ernesta was labelled as crazy during her life, and after her death. For many years, she was overcome by feelings that Roland Barthes would later describe as a "feeling of sickening boredom" (Bartnes, 2006, pp. 200-201). Anthony Gidens described it as "an individual sense of nonsense" (Gidens, 2002, p. 13). For Ernesta Thot, Weber's "iron cage of modernity" in the art of the avant-garde was too constricting. This affliction, characteristic of modern society, led her to become the first romantic heroine in the history of art curation. Until the end of her days, she believed that art has the power to transform. Like Paul Celan, Ernesta believed that "the artist fulfills the role of a modern alchemist, both in relation to forms and to the meanings that make up a whole culture" (Guzek, 2007, p. 101). 


\section{Ernesta the Bad Ghost}

It is difficult to pick out the moment when she decided to weave this conviction into her area of interest. One day, however, Ernesta was ready "to enter into a sinful relationship with the Evil Spirit" (Beneveni, 1863, p. 458). The catalyst may have been Ernesta's fascination with Barbarogenius (Czaplik-Lityńska, 2005), one of the more unusual fictional characters of the first avant-garde. Barbarogenius had the power to transform beings. For Ernesta, the Expressionists, and the Surrealists, whom he inspired, he became an extraordinary figure from whom they took the belief that "properly used symbolic signs have the power to process and even produce things in the world" (Wierciński, 2010, p. 136), which perfectly fits in with ancient magical thinking.

Magical word had the power to reach an extradimensional world, and many magical practices themselves were "based on the assumption that a name and its object are (intrinsically) connected (...); hence verbal actions are simultaneously actions 'within' objects”' (Szczęsna, 2002, p. 167). It was only after her death that similar demiurgic features would be attributed to the curator of art, and conceptual art as a whole. This idea, this concept - or at least, this belief - just somehow never bloomed: it didn't achieve full expression or articulation. Looking at it now, this lack or prevention from reaching a resolution may have been a factor that (along with others) pushed Ernesta over the edge of sanity.

In an alchemical sense, this mortal breakdown became her point of rebirth, a little like the Phoenix, which hatches from the ashes of its last incarnation. She became a heroine of contemporary art, whose ambitions exceeded her, as did the expectations placed on her by herself and others. The theory she wanted to demonstrate did not evolve to become a sphere for summoning or transporting creations from the realm of dreams and imagination to the realm of reality.

\section{It Takes a Revolution}

Ernesta was convinced that modern art needs a guide, a translator. Appearing in the second half of the twentieth century, the figure of a curator as a master, a ruler, and creator of modern art brings to the mind of some the archetypal hero Barbarogenius: a Messiah, a Saviour, a Destroyer of the Old Order. His causative powers partially correspond with those of a Saviour and partially with those of a Shaman: the curator is partially a channel for the power and authority of a "God," while at the same time preparing for changes, moving balances, and rhythms that only the perspective and experience of a Shaman could reveal. This power cannot be rationally explained, but it is the curator, and no one else, who has the power to possibly cause the expected or unexpected changes. Artists and art theorists contemporary to Ernesta had been 
seeking and looking out for this kind of breakthrough, but they did not completely know the "shape" of the thing they were reaching out for. It is very possible that, for this reason, all their revolutionary ideas and proposals took the form of manifestoes and crazy postulates, whose effects and impact were expected to manifest at some point in recent near-history.

It is without a doubt that Ernesta (as an enlightened and curious person) came across the "Manifesto of Expressionism" by Stanislav Vinaver in 1920. In the manifesto, he writes:

Today we are entering the Spirit of Change, the Spirit of Flow, the Dynamics of Chaos, the revolution of Expression, and what is expressed. And once the revolution is finished, everything will grow, even without much effort on our part. The forces of nature will serve us and revive our revolution. Anyone who desires will not make a revolution/One needs to know how to start the release of words, concepts, imagination - from their limitations and trenches. We, Expressionists, we start a revolution, we enter into chaos, into the endless release of everything from everything.

(Vinaver, 1980, p. 82)

Such a perspective for us today - with the experience of postmodernism just behind us - is not at all that strange. Jameson (2011) mentions that in a "sense that since everything we say is only part of a larger chain or context, all impressions that seem primal are really just links in some larger text" (ibid., p. 402). This mindset can serve as the key to unraveling the enigmatic commentary that Ernesta left in her navy-blue notebook with heavy, hard covers: the sole testament of her life, theories, and thought. Beside the aforementioned section from Vinaver's manifesto, she hurriedly wrote the word "V.I.T.R.I.O.L" in her slightly crooked script, under which (clearly annoyed) she wrote, "Everything is the fault of the Fish!"3

\section{The Alchemist's Manifesto}

Ernesta prepared a manuscript titled "The Alchemist's Manifesto," but in a moment of clumsy misfortune, it "fell into a pool of small, swimming creatures." These creatures had their way with the manuscript, and this unfortunate event, without a shadow of a doubt, redirected the future of the history of art and curating, while also laying the foundations for an unconscious narrative to evolve and surround the manuscript - a narrative that never resonated out loud. Ernesta wrote out her grief surrounding this unfortunate event. These writings at once close the incident, and - by strange paradox - open up the way for us to interpret her concept of the art curator as a Guardian, Alchemist, and romantic Hero. 
In the end, the incidents that surrounded and followed her may be the best indicators of what she meant.

\section{Ernesta's Diary}

To future generations of art and curation researchers, Ernesta Thot became a hidden object of desire and the purest form. In the theories, art descriptions, and exhibitions that these generations of researchers have compiled, presented, and exhibited in the years since Ernesta's death, you can easily find fragments and echoes of Ernesta's thoughts. "Deciphering" these writings is like "taking a walk through a forest of fiction" (Eco, 2007), because Ernesta did not really leave behind an organized text, a complete diary, or something that would allow us to clearly understand her character today. What she did leave us are hurried notes made in the margins of the navy-blue notebook. One such key note is the inscription "V.I.T.R.I.O.L" in the margin of the aforementioned fragment of the "Manifesto of Expressionism." Thanks to this mysterious inscription (and ticket stubs that, by some miracle, simply did not fall out from between the notebook's pages over the course of the ages), we can be very confident of the fact that Ernesta Thot - at a point in her mature life - set out on her own grand tour, during which she came to Greece. Perhaps she spent a few days in Delphi so that (in accordance with the ancient Oracle's maxim) she could "get to know herself." This seemingly familiar maxim was, however, one of the central axioms of alchemists, for whom we know Ernesta had a special respect and affection. The term "V.I.T.R.I.O.L" also refers to the Oracle's maxim: "V.I.T.R.I.O.L" encourages the symbolic descent of "man" to the depths of themselves. "Visita Interiora Terrae Recitificando Invenis Occultum Lapida," meaning "Visit the Interior of the Earth, and by Rectifying, You Will Discover the Hidden Stone."4

\section{Plato's Cave}

During one of her last outings while in Greece, Ernesta was around the island with some friends when they got caught in a rainstorm in one of the many grottos that are scattered in the area (Figure 7.2). To pass the time, this cheerful group performed a shadow theatre on one of the walls of the cave, and told the stories of their - as yet - unrealized artistic ideas. Ernesta eventually became bored with this and went for a solitary wander to explore the depths of the rock labyrinths. Going up along a stony path, she reached the mouth of a cave, where she found strange objects basking in the light of the sun. Wanting to tell her companions about what she had discovered, Ernesta hurried back down the path, but she slipped during this rocky descent. Adding an insult to the injury, not only did she pick up a large bruise, but she was knocked unconscious for 


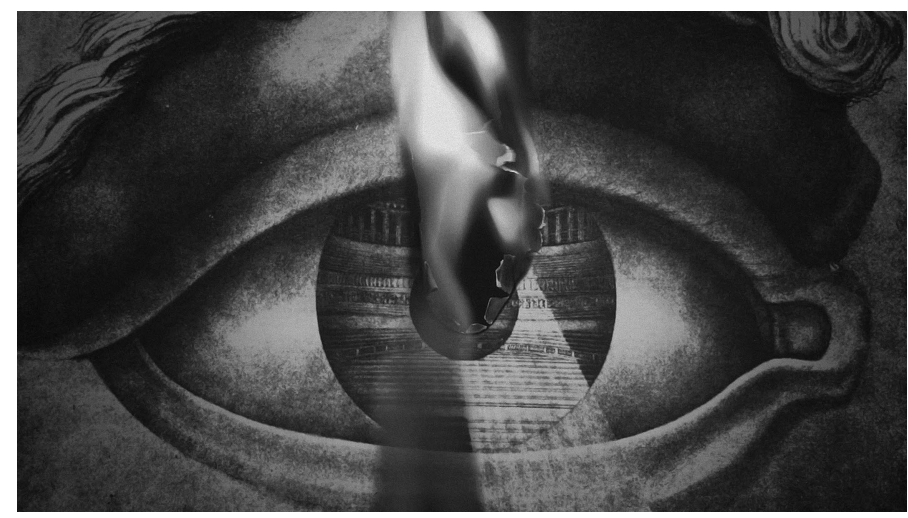

Figure 7.2 Plato's Cave. Jakub Woynarowski (2013), “Nigredo,” frame from the video.

a few moments. Her companions were unsympathetic upon hearing her story and decided that it was evidence of her peculiar madness, attributing this "episode" to the pessimism that was commonly believed to manifest in old maids beyond a certain age. The resulting disputes led to social exclusion for Ernesta, sadly not for the first time. Ernesta herself, however, was inspired by her discovery of - and encounter with - the mysterious objects in the mouth of the cave, and her thoughts crystalized into a concept we now recognize as "the Ready-Made." This concept and approach was popularized a few years later by Marcel Duchamp.

\section{André Rouillé and Ernesta Thot}

An attempt was made many years after Ernesta's death to reconstruct the alchemical source and pedigree of conceptual art and - by logical extension - of contemporary art. This work was undertaken by André Rouillé. Duchamp's shift towards creating art using various common, even mundane objects caused a significant change in the perceptions of the role of the artist, in both the public sphere and the sphere of academics/theorists. The activities of artists were no longer solely concerned with "producing" work, because there was now room (both actual and theoretical) for encountering, noticing, and turning the attention of others to (already) created objects. The modern artist - more than his historical counterpart - had become like a magician, elevating mere things from the mundane and drab, into Works, of massive cultural significance. In order for this to even take place, however, it was necessary to help other magicians - these being critics, curators, and theorists - who place these Works at the centre of art institutions and make them visible to all (Rouillé, 2007). 
An enigmatic reference to Ernesta by Rouillé appears in the following sentences:

Not everything is art, but everything can become it, or rather, every "thing" can become "matter" 5 for art, provided it becomes a part of the artistic process. Thus, art "appears" as a (result of) procedure and as a faith.

(ibid., pp. 341-342)

The full breadth of Ernesta's influence is revealed elsewhere in Rouillés work. Opening the section that considers the relationship between ready-mades and Photography, Rouillé uses the statement "symbolic alchemy is equivalent to (an appropriate) ready-made " (ibid., p. 342), a phrasing that could well have been uttered by Ernesta as she was gripped by a delirium or trance while visiting a vernissage. ${ }^{6}$

\section{Granddaughter of Ladies of Alchemy}

Ernesta's fascination with alchemy and its processes grew over time, moving on to fixation and onto obsession (Figure 7.3). Associating herself with the Surrealists, Cubists, and Expressionists, Ernesta became convinced that she was the heiress of the old masters of alchemy: Philadelphos, Komanos, Zosimos, Jabra Ibna Hajjan, Rhazes, Avicenna, Albert the Great, Georg Bauer (who authored the tome De re metallica), Paracelsus, Michał Sędziwój, John Dee, Edward Kelley, and Nicolas Flamel. She felt that her greatest spiritual relationships were with the legendary alchemists who supposedly had possessed the skill and understanding to create a "Philosopher's Stone": Maria Prophetissa - also called Maria Żydówka, Mary the Jewess- Cleopatra the Alchemist, Medera and Taphnutia, and

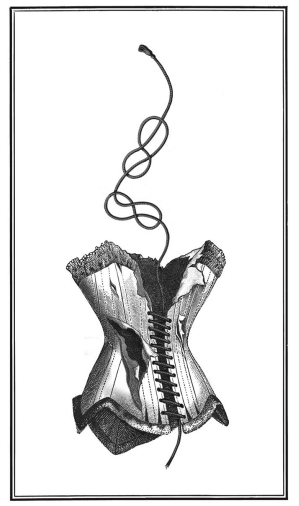

Figure 7.3 Granddaughter of Ladies of Alchemy. Jakub Woynarowski (2013), "Damaged object," "Corpus Delicti" cycle. 
also Paphnutia the Virgin. Based on Cleopatra's story, Ernesta began her own version of the sketch Chrysopoeia of Cleopatra - a mysterious document with an icon of Ouroboros: the symbol of oneness with the cosmos, and eternal return. This document was found close by her, after that fateful stroll through the garden where she encountered the Golden Flower and greeted unconsciousness. Like the alchemists she admired and connected with, Ernesta needs the words of others to tell her story. ${ }^{7}$

\section{The Need for Immortality}

Perhaps Ernesta imagined that she was a visionary who would wake up and overcome her own death one day, and be reborn. Like the "Great Daughters of Alchemy," she cultivated a conviction of her own agency and believed that, like them, she dealt with energy, with what was natural, material, and spiritual at the same time. She tried to combine what was "low," "common" with what was "high" and "noble." 8 What some artists dilated, blurred, or hid in the crevices of the studio, she merged and transformed into new and different forms. Nobody else but Ernesta Thot had the power to transform what is earthly into something spiritual and extraordinary. She looked for reflections and echoes of the ideas she worked with and in the art that surrounded her.

\section{The Operation of the Sun}

In conversations - both real and imagined - about building and creating art exhibitions, Ernesta spotted several similarities with a hermetic tradition called The Operation of the Sun, a tradition alchemists were known to practice (Figure 7.4). There were four stages, each one

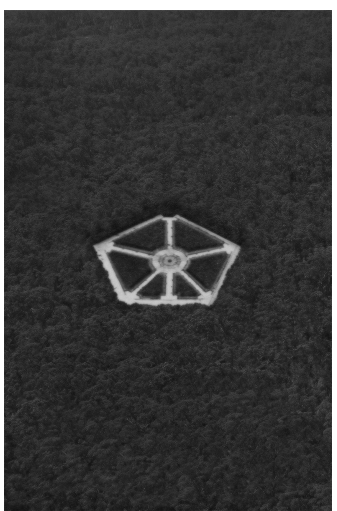

Figure 7.4 The Operation of the Sun. Jakub Woynarowski (2013), "Albedo," "Novus Ordo Seclorum" cycle. 


\section{Marta Kudelska}

corresponding with a particular stage of the alchemist's search for perfection and the continuation of their quest.

The expected transformations would be initiated by heating the correct elements over a fire. The resulting hot, bubbling mass would be black in colour - nigredo - was identified with the primordial state of matter, and was the symbol of "the internal death." This massa confusia (mixed mass) was - despite appearances - a harbinger of future glory and rebirth. The second stage was the process by which the massa confusia returned to its initial form, only now it would be white in colour, having been purified by the fire of the first stage. Due to the white colour, this stage was called albedo. The third stage was called rubedo, during which the white mass would become red in colour. This stage identified with elevation. The fourth stage identified with a rebirth at the highest possible levels and obtaining the Philosopher's Stone. Intuition told Ernesta that her instinctive grasp regarding these processes, and their intrinsic connection to the space in which she could arrange exhibitions, was no haphazard coincidence.

\section{White Cube and Death Mole}

The "ideal" gallery strips away from a given artwork all of the clues and markers that would interfere with the "clear" fact that the artwork is an Artwork. It (the Artwork) is isolated from anything that could diminish its intrinsic (of itself) value. This endows the gallery with the "remit" to possess spaces with the attributes of other places, in which conventions are maintained by creating a system of closed values. By combining the feeling of sanctity from a church with the formal structure of a courtroom, and the mystique of an experimental laboratory with a chic layout, a unique aesthetic "chamber" is created.

(O’Dohery, 2005, pp. 452-453)

The focus of the perceptive fields within such a space are so strong that outside of this space, art objects seem to "shrink" and slip down to the order of the mundane and everyday. The opposite is also true, in that "things" become art in a space that is able to focus artistic ideas around them (Figure 7.5).

In reality, the (art) object often becomes a "medium" (or a catalyst) around which particular ideas crystalise and, in turn, become the subjects of conversation and debate; this is a popular form of academic late-Modernism (...the ideas are more interesting than the actual art ...).

The sacramental aspect of the space becomes clear, as does one of the Great Immutable Laws of Modernism: as Modernism ages, 


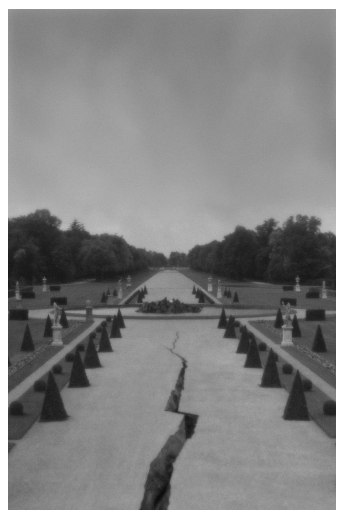

Figure 7.5 White cube and death mole. Jakub Woynarowski (2013), “Nigredo,” "Novus Ordo Seclorum" cycle.

its Context becomes its Content. By some strange twist, the objects within the gallery "frame" the gallery, and define its jurisdiction.

(O’Dohery, 2005, pp. 452-453)

Brian O'Dohery writes about this extraordinary space for the presentation of art. In this "aesthetic chamber," Ernesta enacted the second stage of the alchemical process - albedo. To Ernesta, this strange and seemingly irrational place was like the abyss: "in order to get there, you must be already dead" (ibid., p. 453). The art objects Ernesta saw there filled her with fear, but still she looked at them with child-like fascination. It was akin to the time when she was five, and she buried a dead mole she had found and covered it with a piece of glass. Over the following days, she returned to this place and would clear the earth back from the glass with her fingers, revealing the cold, transparent border that divided her from death and decay. Art in galleries was dead in just the same way, but that was a price that had to be paid for the next step of its existence.

\section{Night Butterfly}

The first stage in the process of transmutation in preparation for an art exhibition, according to Ernesta, was the symbolic immobilization of the artistic object. Circling like a night butterfly, she set about searching artists' workshops for eye-catching objects: paintings, sculptures, notebooks, posters, mugs, cutlery, sketches, installations, pens, toothbrushes, beads, knick-knacks, including also books, albums, and photographs. Sometimes she had to take great pains in order to get the object of her desire. Artists did not willingly give her their works or souvenirs, 


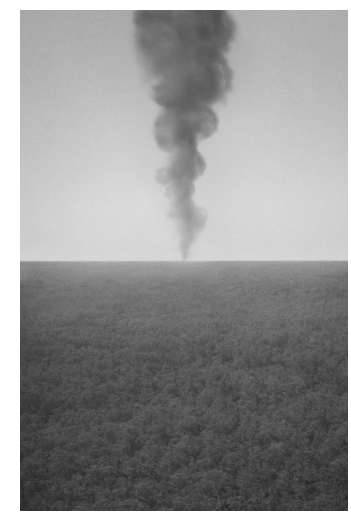

Figure 7.6 Night butterfly. Jakub Woynarowski (2013), "Rubedo," “Novus Ordo Seclorum" cycle.

but seeing her slightly demonic look thought the better of it than refusing her. Ernesta - satisfied - would then disappear from those dark, dusty places hidden between the alleyways of shabby neighbourhoods, leaving behind only the rustling sound of her long, black cloak. She hid her treasures, like many other exhibition creators, away from prying eyes in storage units, safes, caskets, and lockers (Figure 7.6). Every now and then, she took her notebook, and staying alone with the object, wrote down its characteristics, applicability, history, and curiosities. Like the mythological Moirai, ${ }^{9}$ she cut off the threads connecting the object with reality and let it have one, only one, function: being an object to look at (O'Dohery, 2005). Once the last thread was broken, the object was "torn out of life practice" (Bürger, 2006, p. 61). It became "nothing" and therefore potentially "Everything." Thus, the next stage of sublimation could take place - albedo.

\section{Filius Philosophorum}

In her mad raptures, gigglingly nervously, Ernesta had no doubt that she had discovered one of the many mysteries of the world. How could she be wrong, since even the walls of the gallery were white and it was right there: on the pedestal, in the glass case, behind the windows, on the platforms, that the "art" was regaining its value and meaning? Ernesta did not believe in the randomness of those clues. The last stage of these transformations, the final effect of her hard work, the Opus Magnum, was rubedo - the final elevation, involving the manifestation and revelation of Art by its Follower (Kudelska, 2019). The researcher Carol 
Duncan wrote about places that could reveal this alchemical process, repeating after Victor Turner:

[T] hey can open a space in which the individual can distance himself from practical issues and social relations of everyday life and look at himself and his world - or certain its aspects - in a different way.

(Duncan, 2005, p. 285)

In today's world, museums and places for the presentation of art are supposed to be special places, marked out with an unusual aura, where the supernatural transformation of the well-known world was to take place. When the anticipated changes had run their course, Filius Philosophorum (philosopher's stone) started to materialize. And what of it, that it did not look like stone? Well, Ernesta was of the opinion - like many of her significant (legendary) predecessors - that it did not have to be limited to one final form and shape, but that it most surely granted immortality. Although this did not play out for Ernesta Thot, she - on opening nights, while drinking red wine - believed that the art was gaining immortality with every passing moment.

\section{Emerald Array}

While looking through Ernesta's navy-blue notebook (Figure 7.7), next to a ticket from a trip to Greece, you can find another clue revealing yet another plank of her art theory, which was about to manifest and appear in the pages of "The Alchemist's Manifesto," the one that sank and was nibbled by the fish. This time, her hand is less hurried, and it appears that Ernesta has had the time to lay out every word carefully:

What is lower is like what is higher, and what is above is like what is below, for miracles penetrate/pass through only "One" thing.

$$
\text { (Bugaj, 1991, p. 120) }
$$

It seems that her bizarre adventure in the grotto - which does evoke associations with Plato's cave - was not a fabrication of some hysterical old lady, but an actual extraordinary, revelatory event. The quote itself presented by Ernesta comes from the text Corpus Hermeticum (written between the third century BC and the third century AD), and named after its legendary author, Hermes Trismegistos. One of the most important texts of this collection was the so-called Emerald Array, which was considered a crucial key to the creation of a Philosopher's Stone. The sentence Ernesta so carefully wrote indicates clearly that she had stumbled onto the next element of this amazing puzzle, which she might have created herself. However, we can reasonably 


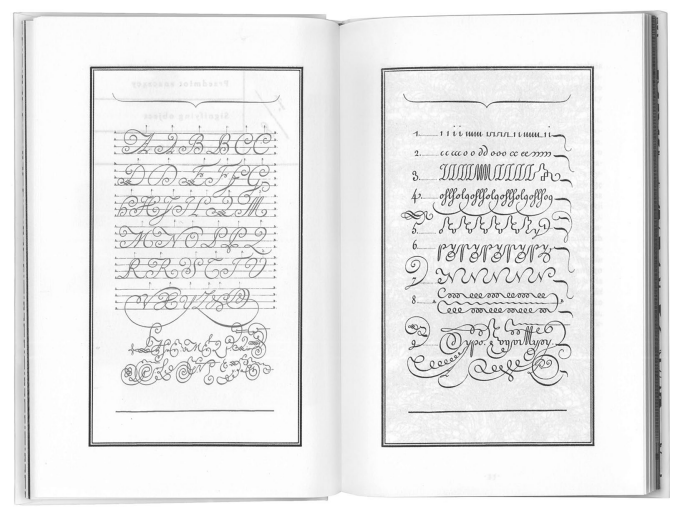

Figure 7.7 Emerald Array. Jakub Woynarowski (2013), "Signifying object," "Corpus Delicti” cycle.

speculate that, once again, she sensed "something" coming. Looking carefully at the yellowed sheet, under the visibly rough section of the paper, you can see an arrow directing our eyes towards the slogan "Fountain." No doubt about it, Ernesta's directing us to Marcel Duchamp's "Fountain."

\section{Plato, Aristotle, and Duchamp}

The philosophers who inspired Ernesta in her alchemical search were Plato and Aristotle. The Platonic Science-of-Ideas as the hierarchy of perfect beings was one of the foundations for alchemists who strove for perfection. Like the ancient philosophers, the alchemists and Ernesta were convinced that by perfecting their knowledge, they perfected themselves. Hence - probably - her compulsive need to collect various (now lost) objects and books, in which she saw the order for ruling the world. For her, these strange collections became a mirror reflecting and indicating the rules that governed human culture (Clifford, 2010). Guided by the old alchemical principle of solve et coagula (dissolve and coagulate), she built and connected her objects' most diverse stories to each other. Like Plato in "The Feast," she believed that first she should know material things (Platon, 1984), but her real purpose was to reach the essence of things, the so-called fifth disclosure, which she found out about while looking through "Letter VII" (Platon, 1987, p. 341). In this way in ages past, alchemical thought and recognition had been arranged and ordered, and Ernesta internalized this order too. She examined and investigated the world and art around her, attempting to discern their laws and mechanisms, all of which would help her capture that which was invisible, and rise above everyday life. Unlike Plato, she was not so 
critical of art, and did not think that she should get rid of it. Looking at the achievements of her contemporaries, she became convinced that they had accomplished something

that - even though it was a deep desire and intention of Plato could not be realised in that time: Art, as a result of internal change evolved into a philosophy, which resulted in a cascade of multiple serious changes.

(Sosnowski, 2007, p. 138)

In her opinion, the alchemical transformation of things into art, which Duchamp had achieved, was nothing more than a question about the cause of the creation of art (ibid., p. 138). Ready-Mades were nothing more than the fulfillment of the sentence from the Emerald Tablet, and thus conceptual art ceased to use objects and focused on ideas.

The Aristotelian quinta essentia (fifth essence), which alongside the four basic elements made up the world, was something volatile, elusive, immaterial, and invisible; it became for Thot a new quality in art, which only a few years after her death would manifest in the form of land art, ephemeral art, and performance, ${ }^{10}$ but also appeared in the form of a curator of art, who "should always be open to surprise, so that the unexpected may happen" (Obrist 2010 cited in Krawczyk, 2016, p. 79). Ernesta Thot's crazy ideas came from the fact that she was always ready for a surprise.

\section{An Ending That Is Also a Beginning}

The Alchemical Life (...) is the first text in the form of a verbal and artistic collage devoted to the alchemical heritage of Ernesta Thot (...-1936). Over eighty years after her death, Thot is an extremely forgotten figure, and her intellectual achievements remain one of the most dispersed and obscure perspectives of twentieth-century art and curatorship. Though forgotten, and so very on the fringes, this proto-curator and researcher appears marginally as a recurring echo of the magical, surreal, and alchemical narratives present in art. None of Ernesta Thot's texts have survived to our times and no photographs of her are available. The navyblue notebook with its hard covers, that is mentioned here, does not exist either. The author's aim is not to fill this gap, but to reflect on the potentiality, possibility, and vitality of the ideas of this extraordinary woman. Her biography is full of gaps and ambiguities. We do not know when she was really born or that she really died. Looking at the traces she left, one can point out that her character bears the typical hallmarks of a romantic hero. Undoubtedly, Ernesta, like all future curators, was characterized by individualism, a premonition that individual happiness is not dependent on the general public, and was also convinced of its uniqueness and charisma. Her thoughts were directed towards great 
ideas and she felt torn between what was here and what was there. That is why, like all romantics, she dreamed she was where she was not (Janion, 2010). She also had a conviction of her own prometheanism, characteristic of the romantics, and a certain dark fatality, which manifested itself in inexplicable events whose aim was to cover up all the traces she had left behind (ibid.). This dark fatalism is revealed in the story of a cave expedition, and when Thot destroys her "Alchemist Manifesto" through her own apparent momentary clumsiness. What was in it really? Was it really all the fish's fault...? It is unlikely we will ever find out.

Focusing on contemporary texts, appropriating certain theories, events and thoughts, I created a fiction - a potentially possible story (Figure 7.8). Potentially, because Ernesta Thot never really existed...

Except on these pages...

However...

The figure of a mysterious woman in a black coat appeared in my head thanks to the many conversations I've had with the visual artist Jakub Woynarowski. He is a lover of conspiracy theories in art, and he explores potentially possible narratives at the junctions of modern art and secret teachings such as alchemy, as well as mysterious groups like the Freemasons. After these many years of conversations, particular strands, strange clues, and premonitions began to appear before me, which (after "heating," purifying, and crystallizing) took the form of Ernesta and her "peculiarities." When I read books about art, I started to stumble across strange, resonant passages, and by chance, I found historical female alchemists. In my curatorial activity, I have begun to turn ever more towards the amazing and the magical, but also towards terror and mystery.

To sum up, everything indicated that Ernesta Thot was crazy? A lunatic? A romantic? Although she has never existed, she had to be "born" in

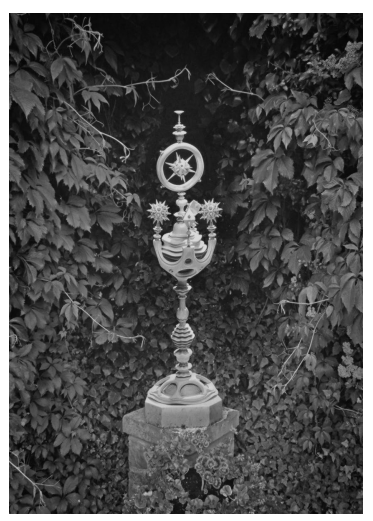

Figure 7.8 An Ending That is also a Beginning. Jakub Woynarowski (2012), "Geometria et Perspectiva," "Novus-Ordo-Seclorum” cycle. 
order to present her never-created theory. As her creator, I accepted this fact with joy and undisguised relief that the figure who appeared in my head during a certain sunset by the sea (of all places!) finally said who "she" was.

A few clarifications are due here for the Honorable Reader. The first is undoubtedly the heroine's surname and its two-part origin. Let us start with the first one. Thot is not a random name. In the beliefs of ancient Egypt, Thot (or Thoth) was the god of the moon, but also a patron of wisdom. It was believed that he invented writing, and also the calendar, music, and numbers. Ancient Egyptians considered him the Patron of Writers, people of Science and Art. Thot was also the one who invented magical and sorcerous formulas. It was he who escorted souls to the Kingdom of the Dead and acted as an intermediary between the two worlds. His Greek counterpart was none other than Hermes - a winged, cunning youth who was also called a god with two faces. Like his Egyptian counterpart, he mediated between the World of the Living and the World of the Dead; only he could travel between two worlds with impunity. Both Thot and Hermes were Gods of Magic, because they knew all the mysteries of the Heavens, all the secrets of the Earth, and all those secrets still hidden deep within the Earth. Ancient Greece and Egypt are considered to be the cradle of alchemy, so it is not surprising that as a result of a confrontation between these two cultures in the second century, the archetypes of Hermes and Toth began to cross-identify. The result was the aforementioned legendary figure of Hermes Trismegistos, whose persona inspired alchemists right up to the seventeenth century (Nawrot, 1999)!

The function of the intermediary between the two worlds immediately evoked in me the idea - or even the recognition of the core concept - that the role of the curator is to be that one who is the bridge between the world of Art and the world of the Public. It was mentioned, for instance, by Michael Brenson (1998) or Aurelia Nowak (2019) for whom the curator's function is indispensable, even as its scope (and list of required qualifications) expands with time. French researcher André Rouillé, quoted in the text, also pointed to the dependence between particular figures in the art world, but unlike Pierre Bourdieu, he did not see this dependence in the field as a struggle for authority (or "among authorities") (Bourdieu, 2007), but as some magical skill. This magical metaphor illustrates perfectly the way of thinking of people unrelated to art, for whom the processes occurring in art are not of a completely clear nature, and result from some strange, mysterious practices. By assembling all these elements together, I could not call Miss Ernesta differently, as she was supposed to be a subtle precursor to curating, a person who was discovering the alchemical and unusual side of modern and contemporary art.

Ernesta Thot has a double "Styrian-Polish" origin. The latter because of what Maria Janion faced in the "Amazing Slavdom" (Janion, 
2006) - a great, inarticulate phantasm of Polish culture, which - due to its rapid baptism in 966 - was supplanted, becoming an "unconscious core" (Freud, 1982), which re-emerges every now and then in the form of ghosts and phantoms harassing Polish culture, art, and also politics (Sowa, 2011). This perspective seemed to me extremely tempting, especially from the perspective of Central and Eastern Europe as the "Orient of Europe" (Wolff, 1996) - a place that is wild, inaccessible, torn by strange forces so different from the law and order of Western Europe. To heighten this feeling of strangeness as Ernesta Thot's second homeland, I pointed to Styria - a land in the eastern Alps located in the basin of the Drawa, Mura, and Raba.

This strange land, like the whole of Central Europe, has been known for centuries as a land full of dark tales. The Herberstein family, which settled in Gorzanów in the seventeenth century and lived there until the twentieth century, also came from there. One of the members of this mysterious family who put the sculpture of a vampire on the gate to his palace was named Ernest. I could not determine if he had ever been in the castle in Gorzanów. Nevertheless, he was a priest, so contact with mystics, God's madmen, or bards undoubtedly occurred in his life story. Hence, Miss Thot had to have a name coming from this strange land that figured in her ancestry.

Ernesta Thot liked to play with a mysterious and dreamlike art and tracked its relationships with alchemy. The history of the latter is still full of gaps, insinuations, and ambiguities for us today. That is why I decided on a "jolting" narrative, reminiscent of Walter Benjamin's way of telling a story in Pasaze (The Passagenwerk). It was the best way to present this mysterious story. I could not imagine talking about this character and the dependencies discovered by her using "scientific cosiness" (Benjamin, 2005, p. 914), and a narrative full of gaps was closer to the aesthetics of automatic surrealist poetry, which no doubt Ernesta Thot would read and engage with. Anyway, the "literary" perspective in the visual arts is not a new phenomenon. It is enough to mention a significant part of Sebastian Cichocki's texts, the literary experiments of Norman Leto, Łukasz Ronduda, or Roberth Smithson. However, the main inspiration for me was Agnieszka Taborska's prose about Leonora de la Cruz and Phoebe Hicks.

By presenting this text to the Honorable Reader, a text full of alchemical echoes that from time to time reverberate in contemporary art, I wanted Ernesta Thot to become an incarnation of the many phantasms and strange contents present at the crossroads of art and alchemy. This phantom heroine was supposed to be a pretext to tell a hidden chapter in the history of art, the history of exhibitions, and the curator's profession. The story of Ernesta Thot, although fictitious, seems to be dangerously real, and the echoes of magical thinking every now and then are discussed by various researchers, including those mentioned in the text. 
It remains to be hoped that Ernesta Thot can become more realistic and may eventually announce her "Alchemist Manifesto."

\section{Notes}

1 Almost 30 years after her death, this thought will develop under such researchers as Peter Vergo and Carol Duncan. Artists also initiate and engage with a phenomenon called "institutional criticism," involving the disclosure of hidden sub-texts in the museum and exhibition message.

2 The motif of a golden flower is one of the symbols of initiation in eastern alchemy.

3 In alchemy itself, the fish symbolizes the secret substance of the arcanum; as a result of its transformation, a philosopher's stone is created. The fish is also a symbol of the unconscious, something small floating in a great sea full of undiscovered contents. For Jungian psychoanalysis, the fish was a sign of the Self - the unconscious, something hidden beneath the surface of the psyche. Sometimes this impossibility of discovering these contents, their unawareness, could be Jung's reason for multiple neuroses and psychiatric diseases. It is likely that such neuroses eventually led Thot to madness.

4 Acrostic poem created by the alchemist Basil Valentina.

5 Matter, as in "material." A raw material that can be utilized in the production of/generation of/evolution of/elevation of art.

6 Vernissage - French - before the varnish (is applied), a term to describe a private opening of an exhibition before it was opened to the general public.

7 Thot was not alone here. During her conversation in 2007 with Hans Ulrich Obrist about the origins of her curatorial practice, Lucy Lippard stated that she did not even have documentation of her first activities. This peculiar "amnesia," concerning not only Lippard but other founders of modern curation, became the starting point for "a protest against forgetting" and the creation of something like a patchwork about curating (Obrist, 2008/2016, pp. 205-206).

8 A similar way of working can be seen in the curatorial action of Harald Szeemann, or in the project of the "Museum of the Eagle" by Marcel Broodthaers, "Mnemosyne Atlas" by Aby Warburg, or essays "Ways of Seeing” by John Berger.

9 Greek myths - Moirai the Three Sisters of Fate, who wove out the Threads of Life, Destiny, and Fortune for Mortals and Gods alike.

10 Once again, the premonitions of Ernesta Thot turned out to be accurate, see P. Możdżyński, Inicjacje i transgresje. Antystrukuralność sztuki XX i XXI wieku w oczach socjologa, Warszawa 2011, pp. 97-106.

\section{References}

Bartnes, R. (1980/2006). Światto obrazu. Uwagi o fotografiach (La chambre claire. Note sur la photographie). Warszawa, Poland: Wydawnictwo Aletheia.

Beneveni, F. (1863). Dzieje alchemii, czyli nauki o kamieniu filozoficznym. Przeglad Europejski, II(4), 403-483.

Benjamin, W. (1982/2005). Pasaże (Passagen - Werk 1927-1940). Kraków, Poland: Wydawnictwo Literackie.

Bourdieu, P. (1992/2007). Reguty sztuki: geneza i struktura pola literackiego (Les Règles de l'art. Genèse et structure du champ littéraire). Kraków, Poland: Wydawnictwo Universitas. 


\section{Marta Kudelska}

Brenson, M. (1998). The curator's moment. Art Journal, 57(4), 16-27.

Bugaj, R. (1991). Hermetyzm. Wrocław, Warszawa, and Kraków, Poland: Wydawnictwo Orion.

Bürger, P. (2006). Teoria awangardy oraz Burkhardt Lindner Zniesienie sztuki w praktyce życiowej? O aktualności dyskusji na temat historycznych prąów awangardowych. Kraków, Poland: Universitas.

Clifford, J. (2000/2010). Ktopoty $z$ kultura (The predicament of culture. Twentieth-century etnography, literature and art). Warszawa, Poland: Wydawnictwo Aletheia.

Czaplik-Lityńska, B. (2005). Chorwacka i serbska awangarda w perspektywie badań porównawczych. Katowice, Poland: Wydawnictwo Uniwersytetu Śląskiego.

Danto, A. C. (1964). The artworld. Journal Philosophy, 61(19), 571-584.

Duncan, C. (2005). Muzeum sztuki jako rytuał. In M. Popczyk (Ed.) Muzeum sztuki. Antologia (pp. 279-299). Kraków, Poland: Universitas.

Eco, U. (1994/2007). Sześć przechadzek po lesie fikcji (Six walks in the fictional woods). Kraków, Poland: Wydawnictwo Znak.

Freud, Z. (1916/1982). Wstęp do psychoanlizy (Vorlesungen zur Einfubrung in die Psychoanalyse). Warszawa, Poland: PWN.

Gidens, A. (1991/2002). Nowoczesność i tożsamość. „Ja” $i$ społeczeństwo w epoce późnej nowoczesności (Modernity and self-identity. Self and society in the late modern age). Warszawa, Poland: Wydawnictwo Naukowe PWN.

Guzek, Ł. (2007). Sztuka instalacji. Zagadnienie zwiazku przestrzeni i obecności w sztuce wspótczesnej. Warszawa, Poland: Nerition.

Jameson, F. (1989/2011). Postmodernizm, czyli logika późnego kapitalizmu (Postmodernism, or, the cultural logic of late capitalism). Kraków, Poland: Wydawnictwo Uniwersytetu Jagiellońskiego.

Janion, M. (2006). Niesamowita Słowiańszczyzna. Kraków, Poland: Wydawnictwo Literackie.

Janion, M. (2010). Prace wybrane. Zło i fantazmaty Tom 3. Kraków, Poland: Wydawnictwo Universitas.

Krawczyk, L. (2016). Co dzisiaj znaczy być organizatorem wystaw?. In Zeszyt realizatora / realizatorki wystaw. Kraków, Poland: Galeria Sztuki Współczesnej Bunkier Sztuki.

Kudelska, M. (2019). Novus Ordo Seclorum - z Kuba Woynarowskim rozmawia Marta Kudelska. Retrieved on 21-06-2019 from www.punktmag.com/ punkt-10/

Możdżyński, P. (2011). Inicjacje i transgresje. Antystrukuralność sztuki XX $i$ XXI wieku w oczach socjologa. Warszawa, Poland: Wydawnictwo Uniwersytetu Warszawskiego.

Nawrot, L. (1999). Źródła hermetyzmu i alchemii. Nowa Krytyka, 10. Retrieved on 22-06-2019 from http://bazhum.muzhp.pl/media//files/Nowa_ Krytyka/Nowa_Krytyka-r1999-t10/Nowa_Krytyka-r1999-t10-s179-199/ Nowa_Krytyka-r1999-t10-s179-199.pdf

Nowak, A. (2019). Curatorialethicsw Kunsthalle Wien. Retrieved on 22-06-2019 from www.magazynsztuki.eu/teksty/curatorial-ethics-w-kunsthalle-wien/

Obrist, H. U. (2008/2016). Krótka historia kuratorstwa (A brief history of curating). Kraków, Poland: Wydawnictwo Korporacja Ha! Art. 
Obrist, H. U. (2010). Foreworld. In C. Thea (Ed.), On curating. Interviews with ten international curators (pp. 2-10). New York, NY: D.A.P. Distributed Art Publishersp.

O’Dohery, B. (2005). Uwagi o przestrzenii galerii. In M. Popczyk (Ed.), Muzeum sztuki. Antologia (pp. 451-467). Kraków, Poland: Universitas.

Platon. (1984). Uczta. Warszawa, Poland: PWN.

Platon. (1987). Listy. Warszawa, Poland: PWN.

Rouillé, A. (2005/2007). Fotografia. Między dokumentem a sztuka wspótczesna (La photographie). Kraków, Poland: Wydawnictwo Universitas.

Sosnowski, L. (2007). Sztuka. Historia. Teoria. Światy Arthura C. Danto. Kraków, Poland: Collegium Columbinum.

Sowa, J. (2011). Fantomowe ciało król. Kraków, Poland: Wydawnictwo Universitas.

Szczęsna, E. (2002). Słownik pojęć i tekstów kultury. Warszawa, Poland: Wydawnictwo Akademickie i Profesjonalne.

Vinaver, S. (1980). Manifest szkoły ekspresjonistycznej. Literatura na Świecie, 9(113), 75-82.

Wierciński, A. (2010). Magia i religia. Szkice z antropologii religii. Kraków, Poland: Wydawnictwo Nomos.

Wolff, L. (1996). Inventing easter Europe. The map of civilization on the mind of the enlightenment. Stanford, CA: Stanford University Press. 